https://doi.org/10.5817/RPT2017-1-4

\title{
ROZMĚRY CITACÍ V PRÁVU A ANOTAČNÍ KONVENCE*
}

\author{
JAKUB HARAŠTA ${ }^{A}$, JAKUB MÍŠEK ${ }^{A}$, MONIKA HANYCH ${ }^{B}$, PAVEL \\ LOUTOCKÝA ${ }^{A}$, MICHAL MALANÍK ${ }^{B}$, JAROMÍR ŠAVELKA ${ }^{C}$, MARKÉTA \\ ŠTĚPÁNÍKOVÁ ${ }^{B}$, MATĚJ MYŠKA ${ }^{A}$
}

\begin{abstract}
ABSTRAKT
Článek prezentuje metodologii pro provádění citační analýzy české judikatury jakožto nástroje, který umožní přesnější poznání toho, jak české soudy pracují při své argumentaci sodkazy na jiná rozhodnutí a dalši dokumenty. Prezentovaná metodologie popisuje odkaz jako prvek textu tvořený čtyřmi konstituenty. Jsou jimi ZDROJ, CÍL, ARGUMENT a POLARITA. Tvrdíme, že pomocí těchto konstituentů je možné detailně popsat kvantitativní i kvalitativní vlastnosti jednotlivých odkazů a umožnit tak jejich smysluplné zkoumání. Každý konstituent je dále vnitřně strukturován tak, aby bylo možné (1) překonat aktuální nedostatky citační praxe českých soudů a (2) vytěžit z odkazu maximum informací pro další analýzu. Struktura jednotlivých konstituentio je v článku detailně popsána a odůvodněna. V závěru článku jsou představeny výzvy pro další výzkum $v$ oblasti citační analýzy. Představené ideální kategorie nejsou univerzálně použitelné pro jakýkoli výzkum. Jsou nicméně naformulované v podobě, která
\end{abstract}

Dřívější verze tohoto textu byla prezentována dne 26. 11. 2016 na konferenci Cyberspace v Brně. Děkujeme účastníkům za jejich komentáře. Vznik tohoto textu byl podpořen Masarykovou univerzitou v rámci projektu Metodologie citační analýzy judikatury (MUNI/A/0940/2015). Kontaktní mail jakub.harasta@law.muni.cz a matej.myska@law.muni.cz.

A Ústav práva a technologií, Právnická fakulta MU.

в Katedra právní teorie, Právnická fakulta MU.

c Intelligent Systems Program, University of Pittsburgh, USA. 
umožňuje jejich implementaci pro kvalitativní i kvantitativní studie o úloze citací $v$ judikatuře a právu obecně.

\title{
KLÍČOVÁ SLOVA
}

Citační analýza, Judikatura, Právní informatika, Reference

\begin{abstract}
The paper presents a methodology for carrying out citation analysis of the Czech case law as a tool which enables gaining more accurate understanding of how the Czech courts operate with references to other decisions and documents for the sake of their argumentation. The presented methodology describes a reference as textual element consisting of four constituents. These are: SOURCE, TARGET, ARGUMENT and POLARITY. We claim that using these constituents it is possible to thoroughly describe both quantitative and qualitative characteristics of reference, and thus to meaningfully research them, too. Each of these constituents is further internally structured to enable (1) to overcome the shortcomings of current citation practice of Czech courts and (2) to obtain the most information possible from the reference for further analysis. The detailed structure of each constituent is described and justified within the paper. Challenges for further research on citation analysis are expressed in the conclusion of the paper. The introduced categories are ideal and not universally applicable for any kind of research. However, they are formulated in a way that allows their implementation for both qualitative and quantitative types of research focused on the role of citations in the case law and jurisprudence in general.
\end{abstract}

\section{KEYWORDS}

Citation analysis, Case law, Legal Informatics, Reference

\section{1. ÚVOD A MOTIVACE}

Citace pomáhají určovat význam jednotlivých dokumentů a eventuálně i hodnotit vliv samotných autorů. Práce z 50. a 60. let minulého století daly 
vzniknout scientometrice, ${ }^{1}$ z níž dodnes vychází ukazatele relevantní pro akademický růst. Svou roli mají citace i v právu. Umožňují nám dosáhnout efektivnější rešeršní činnosti, kdy citace $\mathrm{v}$ rámci dokumentu slouží jako odkaz na další související dokumenty. Citace tak slouží jako metatext, který poskytuje čtenáři odkaz pro náležitou identifikaci zdroje (dohledatelnost), podporu tvrzených argumentů a jejich vývoj (autoritativní zajištění), ${ }^{2}$ ale rovněž autorské ověření původního zdrojového materiálu (samotná citace v užším slova smyslu). ${ }^{3}$ Právě možnost kontroly zdroje a ověření, zda je odkaz na něj přesný, je neodmyslitelnou součástí citace jako určení místa, kde byla konkrétní informace nalezena. ${ }^{4} \mathrm{~V}$ právním prostředí je pak citace jedním ze základních kamenů soudního rozhodování či odborné literatury, což plyne mimo jiné i z hermeneutického př́stupu k právu, který je $\mathrm{v}$ České republice velmi rozšířený. V systému common law pak hraje odkaz a provázanost rozhodování s předešlou judikaturou výsadní roli díky existenci právního precedentu a ústavního principu stare decisis. ${ }^{5}$ Odkazy však nejsou limitované pouze na tento právní systém, jelikož stále zásadnější roli hrají i v kontinentálním právním systému. To je dáno jak důrazem na zachování právní jistoty, tak i postupnou konvergencí odlišných právních systémů. ${ }^{6}$ Praktická závaznost judikatury je tak i v ČR značná.

1 GARFIELD, Eugene. Citation Indexes for Science. Science, 1955, roč. 122, č. 3159, s. 108111. Také PRICE, Derek J. de Solla. Network of Scientific Papers. Science, 1965, roč. 149, č. 3683, s. 510-515.

2 K tomu více POSNER, Richard A. An Economic Analysis of the Use of Citations in the Law. American Law and Economics Review, 2000, roč. 2, č. 2, s. 383.

3 Ibidem. S. 383-386. Také LIEBLER, Raizel a June LIEBERT. Something Rotten in the State of Legal Citation: The Life Span of a United States Supreme Court Citation Containing an Internet Link (1996-2010). Yale Journal of Law \& Technology, 2013, roč. 15, č. 2, s. 275. Typologii ontologických úrovní zdrojů, na které je odkazováno, rozebírá v české judikatuře konkrétněji HARAŠTA, Jakub. Nejednoznačnost odkazů k soudním rozhodnutím a možnost řešení. Revue pro právo a technologie, 2015, roč. 6, č. 11, s. 19-20.

4 LIEBLER, Raizel a June LIEBERT. Something Rotten in the State of Legal Citation: The Life Span of a United States Supreme Court Citation Containing an Internet Link (1996-2010). Yale Journal of Law \& Technology, 2013, roč. 15, č. 2, s. 275.

5 Jak zdůrazňuje FOWLER, James H. a Sangick JEON. The Authority of Supreme Court Precedent. Social Networks, 2008, roč. 30, č. 1, s. 16, nebo LANDES, William a Richard A. POSNER. Legal Precedent: A Theoretical and Empirical Analysis. The Journal of Law \& Economics, 1976, roč. 19, č. 2 , s. 250. 


\section{CITAČNí ANALÝZA V PRÁVU}

Citační analýzu, jak již bylo výše uvedeno, je možné využít pro snadnější a efektivnější získávání právních informací - skupiny dokumentů, které se navzájem citují, vykazují často společné rysy, čehož je možné využít při rešerši. Tím se ale možnosti citační analýzy nevyčerpávají. Citační analýza je v rámci hnutí Law \& Economics považována za užitečný nástroj pro měření vlivu soudnictví na právní systém. ${ }^{7}$ Kromě toho umožňuje identifikovat skutečnosti a argumenty, které vedly ke konkrétnímu rozhodnutí, ${ }^{8}$ a tím přispět na praktické úrovni k hypertextovému vnímání právních informací nebo transparentnějšímu odlišení aktuálního případu od minulé rozhodovací praxe. Pozornost, jakou zejména právní profese citacím věnují, naznačuje, že analýza citací umožňuje odhalování vzájemných vztahů a může tak pomoci ke zvýšení konzistentnosti soudního rozhodování. ${ }^{9}$

Historicky se tato metoda objevila již na konci 19. století v podobě tzv. Shepardovy citace (Shepardizace) jako metody pro indexaci odkazů mezi jednotlivými soudními rozhodnutími v USA. ${ }^{10}$ Cílem bylo odhalovat vzájemné souvislosti mezi rozhodnutími skrze citace tak, aby bylo možné vystopovat, jakým způsobem se s konkrétním judikátem zacházelo v rámci další rozhodovací praxe. Význam rozhodnutí totiž není dán výhradně jeho textem, ale i tím, jak je dále využíváno soudy pro argumentaci. Shepardizace se stala běžnou praxí pro ověřování, zda je konkrétní rozhodnutí stále

\footnotetext{
MACCORMICK, Neil a Robert S. SUMMERS. Interpreting precedents: a comparative study. Aldershot: Ashgate, 1997, s. 2 a násl.

7 CROSS, Frank. Determinants of Citations to Supreme Court Opinions (And the Remarkable Influence of Justice Scalia). Supreme Court Economic Review, 2010, roč. 18, č. 1, s. 177, nebo FOWLER, James H. et al. Network Analysis and the Law: Measuring the Legal Importance of Precedents at the U.S. Supreme Court. Political Analysis, 2007, roč. 15, č. 3, s. 325326.

8 SHULAYEVA, Olga, Advaith SIDDHARTHAN a Adam WYNER. Recognizing Cited Facts and Principles in Legal Judgements. Artificial Intelligence and Law, 2017, roč. 25, č. 1, s. 124.

9 To již ostatně poskytla citační analýza založená na počtu výskytu citovaného zdroje napříč judikaturou. K tomu více POSNER, Richard A. An Economic Analysis of the Use of Citations in the Law. American Law and Economics Review, 2000, roč. 2, č. 2, s. 382.

${ }^{10}$ Modifikovanou metodu v současné době využívají komerční právní informační systémy, jako je např́klad LexisNexis nebo Westlaw (Key Cite). SASALA, Kathleen M. Shepardizing and Keyciting online. March 25, 2011.
} 
ještě dobrým právem, tedy zda může být argumentačně využito $\mathrm{v}$ dalších př́padech a eventuálně také jakým specifickým způsobem. S nástupem moderních technologií se pak citační analýza stala komplexnější a byla modifikována do podoby širší sítové analýzy. ${ }^{11}$

\section{ANOTAČNÍ KONVENCE}

V českém prostředí nemá citační analýza žádnou tradici. Nad to má za sebou kultura citací v ČR velmi problematické období, ${ }^{12}$ které výrazně znesnadňuje zpracovávání starších rozhodnutí. Tímto textem tak navazujeme na předchozí výzkum, který má za cíl postupně směřovat $\mathrm{k}$ možnosti využít analýzu citací $\mathrm{k}$ rozboru nezamlčených vazeb mezi všemi rozhodnutími Ústavního soudu, Nejvyššího správního soudu a Nejvyššího soudu. Provedení citační analýzy vyžaduje shromáždění dat. Toto probíhá identifi-

${ }^{11} \mathrm{~K}$ tomu v prostředí judikatury Soudního dvora Evropské unie viz PANAGIS, Yannis a Urška ŠADL. Making EU (case)law: Evidence from a paragraph-to-paragraph network on the cases concerning the citizenship of the European Union. In Proceedings of the 15th International Conference on Artificial Intelligence and Law (ICAIL 2015), Law and Big Data Workshop. San Diego, 2015, s. 1-8, PANAGIS, Ioannis a Urška ŠADL. The force of EU case law: An empirical study of precedential constraint. In Legal Knowledge and Information Systems - JURIX 2015: 28th Annual Conference. Amsterdam: IOS Press BV, 2015, s. 71-80 a DERLÉN, Mattias a Johan LINDHOLM. Goodbye van Gend en Loos, Hello Bosman? Using Network Analysis to Measure the Importance of Individual CJEU Judgments. European Law Journal, 2014, roč. 20, č. 5, s. 667-687. V kontextu Evropského soudu pro lidská práva o problému pojednávají LUPU, Yoanatan a Erik VOETEN. Precedent in International Courts: A Network Analysis of Case Citations by the European Court of Human Rights. British Journal of Political Sciences, 2012, roč. 42, č. 2, s. 413-439. V prostředí nizozemského soudnictví viz WINKELS, Radboud, Jelle de RUYTER a Henryk KROESE. Determining the Authority of Dutch Case Law. In ATKINSON, Katie (ed.). Legal Knowledge and Information Systems JURIX 2011: The Twenty-Fourth Annual Conference. Amsterdam: IOS Press BV, 2011, s. 103-112 a WINKELS, Radboud a Jelle de RUYTER. Survival of the Fittest: Network Analysis of Dutch Supreme Court Cases. In PALMIRANI, Monika, Ugo PAGALLO, Pompeu CASANOVAS a Giovanni SARTOR (eds.). AI Approaches to the Complexity of Legal Systems - Models and Ethical Challenges for Legal Systems, Legal Language and Legal Ontologies, Argumentation and Software Agents, Berlin: Springer, 2012, s. 106-115. O kanadské situaci pojednává NEALE, Thom. Citation Analysis of Canadian Case Law. Journal of Open Access to Law, 2013, roč. 1, č. 1, s. 1-60. Situaci v Rakousku pak rozebírá GEIST, Anton. Using Citation Analysis Techniques for Computer-Assisted Legal Research in Continental Jurisdictions. Kvalifikační práce (University of Edinburgh, LLM). 2009, 103 s., GEIST, Anton. The Open Revolution: Using Citation Analysis to Improve Legal Text Retrieval. European Journal of Legal Studies, 2010, roč. 2 , č. 3.

12 Viz BAŇOUCH, Hynek a Zdeněk KÜHN. O publikaci a citaci judikatury aneb proč je někdy judikatura jako císařovy nové šaty. Právní rozhledy, 2005, roč. 13, č. 13, s. 484-495. 
kováním konkrétních řetězců znaků, které se v textech rozhodnutí nacházejí, jako odkazů na další dokumenty. Tento postup, nazývaný anotace, směřuje k opatřování textu metatextem, který identifikuje konkrétní části textu jako náležející konkrétní sémantické či jiné předdefinované kategorii.

Vzhledem ke značnému množství dostupných rozhodnutí a faktu, že počet rozhodnutí neustále značnou rychlostí přibývá, je plně manuální anotace z důvodu časové, materiální i personální náročnosti, nedosažitelná. Žádoucí se jeví automatická anotace, kterou však ztěžuje hned několik aspektů. Prvním z nich je způsob používání citací v soudních rozhodnutích. Část odkazů, které se v rozhodnutích vyskytují, slouží k rekapitulaci procesní historie, argumentů soudů nižších stupňů nebo předložených podání stran. Tyto odkazy jsou v př́padě automatických anotací rozpoznávány také, přitom nám ale ř́kají jen málo o postoji soudu $\mathrm{k}$ dokumentům, na které směřují. Žádným způsobem totiž nepřispívají $\mathrm{k}$ argumentaci. ${ }^{13}$ Druhou překážkou $\mathrm{k}$ automatickému vytěžení odkazů z rozhodnutí je chybějící citační standard, který činí z rozpoznávání odkazů netriviální úkol.

Řešení směřující $\mathrm{k}$ automatické anotaci citací si tak zřejmě nevystačí pouze s jednoduchým regulárním výrazem, byt ten se ukázal jako do značné míry použitelný minimálně pro zjištění, která rozhodnutí jsou citována. ${ }^{14}$ Nejrozumnější cestou se jeví manuální anotace dostatečného množství rozhodnutí pro vytvoření tzv. zlatého standardu, který pak bude využit jako vstupní set pro strojové učení, které využijeme $\mathrm{k}$ automatické anotaci. Pro tento manuálně anotovaný vzorek je nutné zajistit maximální míru vnitřní bezrozpornosti - je tak nutné (1) předdefinovat anotační kategorie, což je ostatně klíčové pro jakýkoli anotační proces a (2) vytvořit jistou anotační konvenci, která objasní anotační pravidla pro manuální anotaci. Př́prava a zveřejnění předdefinovaných kategorií a objasnění jejich vnitřní struktury se děje zejména prostřednictvím tohoto textu. Sou-

\footnotetext{
${ }^{13}$ Srov. MYŠKA, Matěj, Jakub HARAŠTA, Pavel LOUTOCKÝ a Jakub MíŠEK. Možnosti citační analýzy v České republice. Revue pro právo a technologie, Masarykova univerzita, 2016, roč. 7, č. 13, s. 184.

14 Ibidem, s. 170-183.
} 
částí této práce je také anotační konvence s pravidly pro manuální anotaci, která je dostupná na webové stránce projektu. ${ }^{15}$

\section{KONSTITUENTY ODKAZU}

Předdefinované kategorie, kterými lze odkazy anotovat, zahrnují čtyři základní kategorie, které jsou vnitřně strukturované a které nazýváme konstituenty odkazu.

Nejtypičtějšími konstituenty jsou ZDROJ a CÍL. Oba tyto konstituenty vždy reprezentují konkrétní rozhodnutí a vzájemný vztah mezi nimi. Zdrojový dokument odkazuje na dokument cílový, který tím pádem nějakým způsobem využívá v argumentaci. Při sítové reprezentaci je možné představit si jak ZDROJ, tak CÍl jako uzly. Vzájemný vztah mezi nimi (tedy, že jeden dokument je zdrojový a v jeho textu se nachází odkaz na dokument cílový) vytvář́ orientovanou hranu, která spojuje oba uzly a je orientovaná od zdrojového dokumentu $\mathrm{k}$ cílovému. Toto je zcela základní konstituent odkazu, který nesděluje, jakým způsobem je na dokument odkazováno, ale sděluje nám pouhou př́tomnost odkazu - jedná se o ukazatel kvantitativní povahy. Pomocí něj je možné vypracovat sít vzájemných odkazů mezi dokumenty. Tyto dva konstituenty nicméně nevyčerpávají veškeré možnosti citační analýzy.

Dalším konstituentem je ARGUMENT, který umožňuje sledovat účel, za jakým zdrojový dokument odkazuje na ten cílový - jaký konkrétní argument vznáší. Argument může nabývat podoby přímé citace, parafráze nebo odhalení konkrétní nosné myšlenky, na kterou se autor zdrojového dokumentu odvolává a o jejíž autoritu tak opírá svoje rozhodování. Sledování argumentů umožňuje vnést kvalitativní prvek do sítě orientovaných hran (odkazů) mezi uzly (dokumenty). Umožňuje nám například odlišit, že totéž rozhodnutí má dvě zajímavé linky, hmotněprávní a procesněprávní. Tím nám umožňuje dosáhnout podrobnějšího pohledu na citační analýzu, který bude přesnější, než je jen hrubé sledování a počítání kvantity citací.

Posledním konstituentem je POLARITA. Ta de facto umožňuje sledovat, jakým způsobem soud s odkazovaným zdrojem zachází - opírá o něj svoje

15 Dostupné na http://citacnianalyza.law.muni.cz. 
rozhodnutí nebo naopak argument vznesený tímto dokumentem zavrhuje a vymezuje se vůči němu? Rozlišujeme tedy polaritu pozitivní, negativní a neutrální. Všechny odkazy si však nejsou rovné co do rozsahu a hloubky jejich pojednání - soud bud’ na dokumenty pouze stručně odkazuje, nebo je naopak více $\mathrm{v}$ textu rozebírá. Tyto úrovně (označované jako citovaný nebo diskutovaný rozsah) nám dále umožňují dosáhnout podrobnějších výsledků při sledování konstituentu polarity.

\section{PODOBY KONSTITUENTU゚ ZDROJ A CÍL}

Chybějící český citační standard nás nutí vypořádat se s rozdílností vyjádření referencí $\mathrm{v}$ textu, protože jedno rozhodnutí může nést řadu různých označení nebo názvů, od spisové značky přes číslo publikace ve sbírce až po populární název. Chybějící standard způsobuje, že některé použité identifikátory zůstávají čtenářům rozhodnutí nejasné. Přitom se jedná o zcela zásadní element odkazu - odkazovaný dokument musí být dohledatelný, pokud možno bez expertních znalostí a ideálně ve veřejně dostupných databázích.

Jednotlivé konstituenty tak mohou nabývat různých hodnot - jedno konkrétní rozhodnutí se $\mathrm{v}$ textu může vyskytnout s různými označeními. Kromě samotné identifikace dokumentu pomocí konstituentu Cíl tak můžeme při manuální i automatické anotaci zohlednit podobu konstituentů a eventuálně i zkoumat, jakým způsobem se námi sledované konstituenty odkazu v textech různých soudů objevují a projevují. Toto vede $\mathrm{k}$ vnitřnímu strukturování konstituentů.

Zároveň nám třídění pozorovaných konstituentů do různých kategorií umožňuje sledovat, jaké dokumenty případně celé kategorie a podkategorie dokumentů, jsou v rámci rozhodovací praxe citovány častěji než jiné. Např́klad, jak často Ústavní soud cituje odborné monografie? Jak často je vr- 
cholnými soudy citován časopis Právní rozhledy ${ }^{16}$ Toto všechno jsou otázky, na které vybrané výsledky citační analýzy umožní odpovědět. ${ }^{17}$

16 Pro situaci v Německu viz HAMANN, Hanjo. Die Fußnote, das unbekannte Wesen. Potential und Grenzen juristischer Zitationsanalyse. Rechtswissenschaft. Zeitschrift für rechtswissenschaftliche Forschung, 2014, roč. 5, č. 4, s. 501-534.

17 Srov. HARAŠTA, Jakub. K významu citační analýzy při aplikaci práva. Správní právo, 2017, roč. 50. č. 3, s. 154-162. 


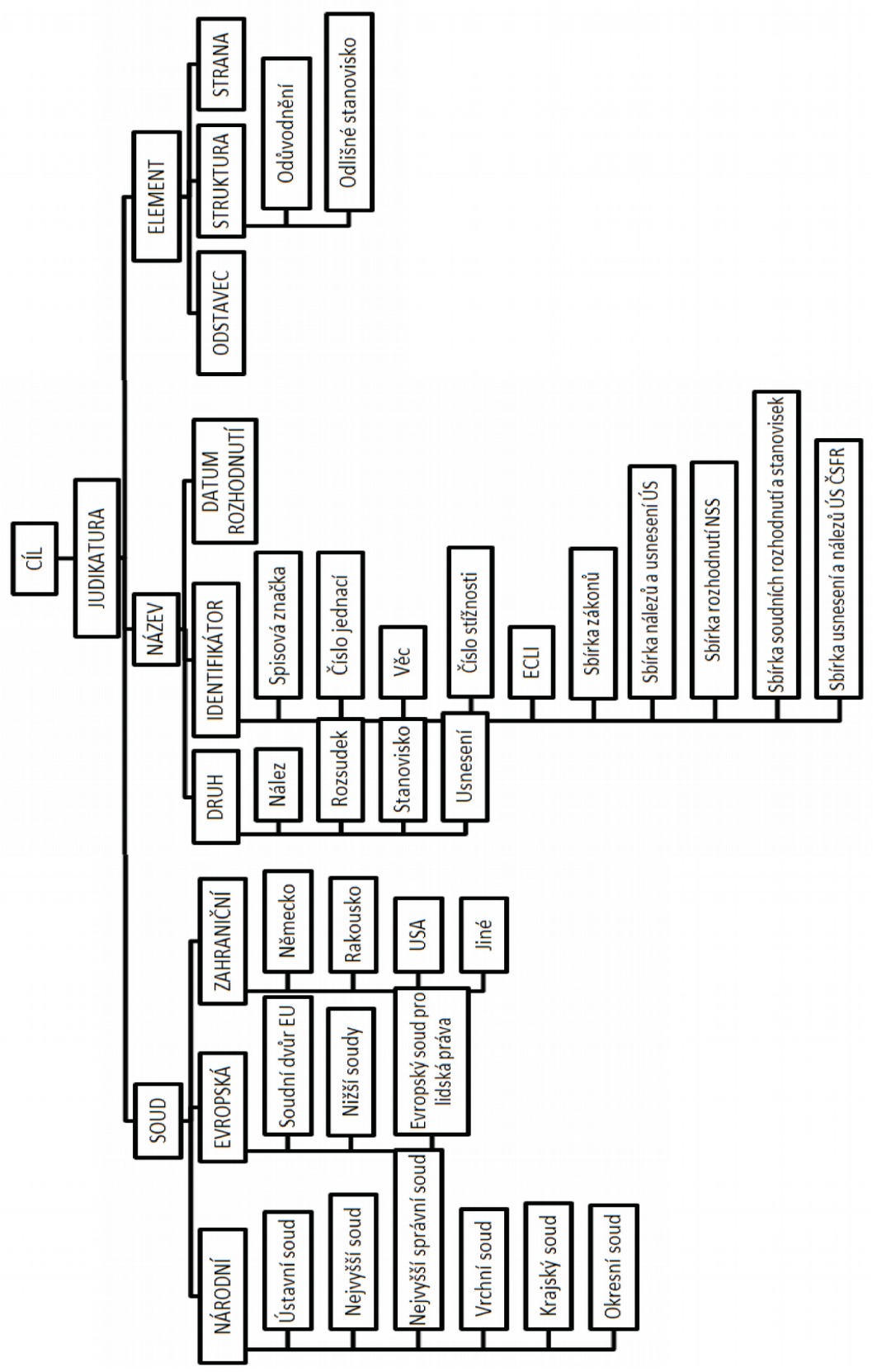

Obr. 1. Judikatorní část konstituentu CílL. 


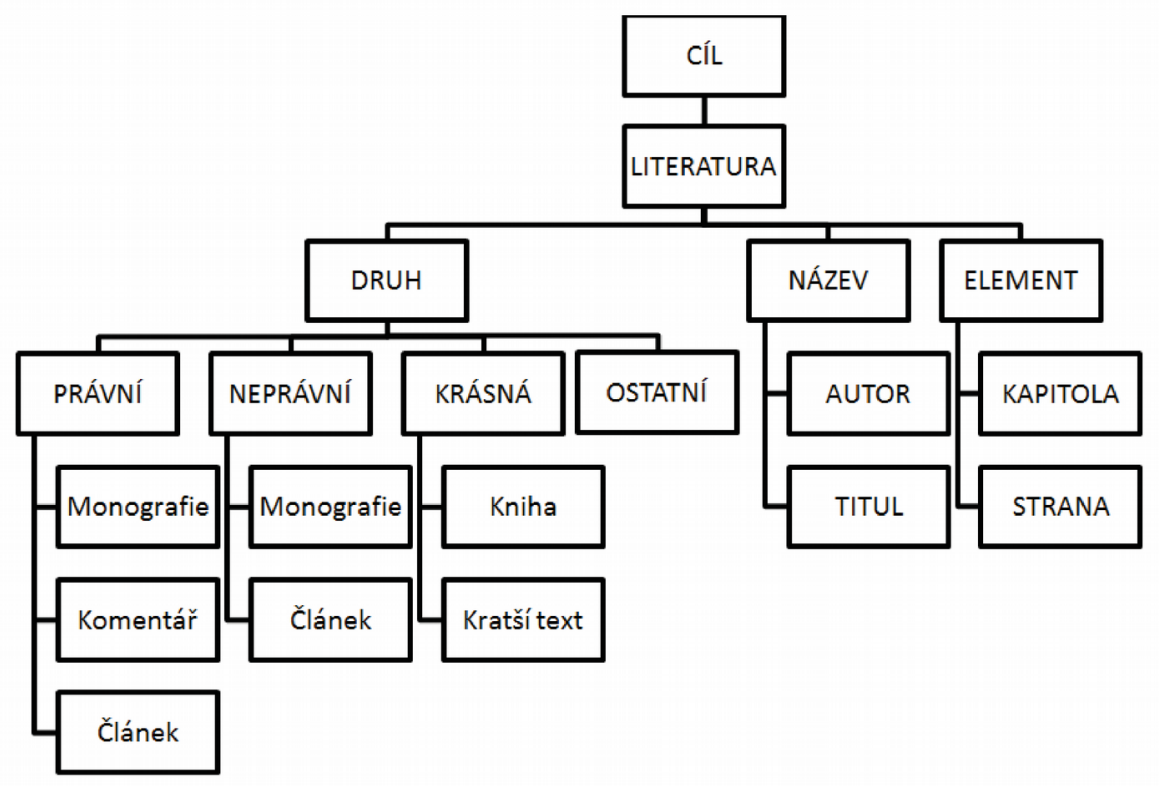

Obr. 2. Literární část konstituentu Cíl.
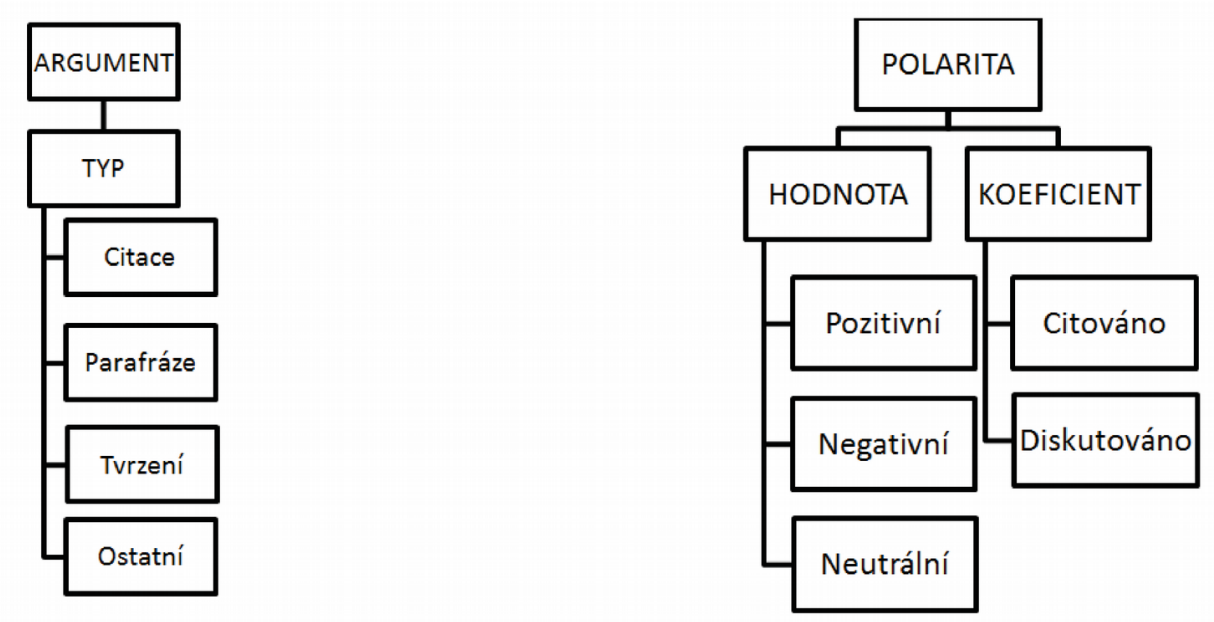

Obr. 3. Konstituent ARGUMENT.

Obr. 4. Konstituent POLARITA. 


\subsection{ZDROJ}

Konstituent ZDROJ představuje poměrně jednoduchou kategorii, kterou je vždy standardizovaná textová identifikace analyzovaného dokumentu. Dokument, který je původcem citace, není v argumentační části textu vyjadřován a není tedy potřeba podrobná definice vnitřní struktury konstituentu ZDROJ. Pro vytváření citační sítě je žádoucí uvádět jako ZDROJ i konkrétní část anotovaného rozhodnutí, např. číslo odstavce, ale to je možné pouze částečně, protože všechna rozhodnutí nejsou tímto způsobem strukturována.

\subsection{CÍL}

Tento konstituent slouží v citaci k identifikaci citovaného dokumentu. Za základní typy cílů považujeme:

1. Judikaturu, kterou dle jejího charakteru dále dělíme na národní, evropskou a zahraniční;

2. Literaturu, kterou dle jejího charakteru dále dělíme na právní, neprávní, krásnou a ostatní.

Jiné druhy dokumentů, jako jsou právní předpisy a správní rozhodnutí, ${ }^{18}$ jsme se rozhodli do citační analýzy nezahrnout. $V$ případě právních předpisů máme za to, že se jim v dostatečné míře věnují komerční právní informační systémy. V případě správních rozhodnutí je důvodem jejich vynechání nízká argumentační síla, kterou v soudních rozhodnutích mají.

\subsubsection{JUDIKATURA ${ }^{19}$}

$\mathrm{V}$ rámci konstituentu CÍL a kategorie judikatura je v naší struktuře citací na nižší úrovni jako první kategorie Národní judikatura. Soudy argumentačně na národní judikaturu odkazují nejčastěji ${ }^{20}$, zejména pak na rozhodnutí vrcholných soudi̊. Argumentační síla odkazů na judikaturu je tak tvořena dí-

${ }^{18}$ Do této množiny patří krom správních rozhodnutí českých orgánů veřejné moci například i rozhodnutí Evropské komise.

19 Viz grafické vyjádření struktury v obr. 1.

${ }^{20}$ Tento závěr vyplynul jako vedlejší poznatek v práci MYŠKA, Matěj, Jakub HARAŠTA, Pavel LOUTOCKÝ a Jakub MÍŠEK. Možnosti citační analýzy v České republice. Revue pro právo a technologie, Masarykova univerzita, 2016, roč. 7, č. 13, s. 173 a násl. 
lem argumentační silou myšlenek v cílovém dokumentu obsažených a dílem postavením cílové judikatury jako zdroje, který by měl soudce ve svém rozhodnutí zohlednit. ${ }^{21}$ Kategorie subtypu národní judikatura pak odpovídají dělení dle soudní hierarchie soudů, které je vydaly. Hierarchické členění nám umožňuje efektivně pracovat $s$ referencí a usnadňuje nám určení a př́padné kvantifikování její argumentační důležitosti. Tato kategorie je tak dále členěna na:

1. Ústavní soud,

2. Nejvyšší soud,

3. Nejvy̌̌ší správní soud,

4. Vrchní soud,

5. Krajský soud (tato kategorie zahrnuje krajské soudy a Městský soud v Praze),

6. Okresní soud (tato kategorie zahrnuje okresní soudy, Městský soud v Brně a obvodní soudy v Praze).

Druhou kategorií judikatorní složky konstituentu Cíl je evropská judikatura. Tu dále dělíme dle soudi̊, které rozhodnutí vydaly, na kategorii Soudní dvůr Evropské unie, do které spadají rozhodnutí vydané Soudním dvorem Evropské unie případně Evropským soudním dvorem v případě starších rozhodnutí, kategorii Nižší soudy, do které spadají rozhodnutí vydaná Tribunálem či Soudem prvního stupně, a kategorii Evropský soud pro lidská práva, do které spadají rozhodnutí vydaná Evropským soudem pro lidská práva. Rozhodnutí těchto soudů mají obecně závazný charakter. V př́ípadě Soudního dvoru Evropské unie jde o harmonizační interpretace evropských předpisů, které jsou pro český právní řád závazné. $V$ případě Evropského soudu pro lidská práva pak rozhodnutím dochází k interpretaci národního práva ve světle jeho kompatibility s Evropskou úmluvou o ochraně lidských práv, kterou je Česká republika vázána a jejíž ustanovení jsou vtělena do českého právního řádu na úrovni ústavního pořádku.

Třetí kategorií je potom zahraniční judikatura, pro kterou byly dle četnosti výskytů na geografickém základě identifikovány podkategorie Ně-

${ }^{21}$ Viz BOBEK, Michal, Zdeněk KÜHN a kol. Judikatura a právní argumentace. 2. Vydání. Praha: Auditorium, 2013, s. 36-39. 
mecko, Rakousko, USA a Jiné. Argumentační síla odkazů na zahraniční judikaturu se liší od odkazů na českou a evropskou judikaturu v tom, že spočívá toliko $\mathrm{v}$ přesvědčivosti uvedených myšlenek. Vzhledem $\mathrm{k}$ naprosté oddělenosti českého právního řádu od právních řádů uvedených států se $\mathrm{v}$ těchto př́padech argumentace nijak neprojevuje právní charakter (závaznost) citovaných dokumentů. Německo a Rakousko bylo vybráno rovněž z důvodu historické a kulturní blízkosti zmíněných právních kultur $\mathrm{s}$ tou českou. Díky tomu narůstá argumentační přesvědčivost odkazovaného tvrzení. ${ }^{22}$ Do kategorie Jiné spadají krom národních soudů dalších států rovněž mezinárodní soudy, jejichž rozhodnutí nejsou pro české právo přímo závazná. ${ }^{23}$ Př́mo k této kategorii nebylo doposud provedeno samostatné anotační cvičení, předpokládáme však možnost značné analogie $s$ národní judikaturou.

Jednotlivá rozhodnutí jsou dále identifikována pomocí kategorie Název, tvořeného:

1. kategorií Druh, s podkategoriemi odpovídajícími názvu dokumentu (Nález, Rozsudek, Stanovisko, Usnesení),

2. kategorií Identifikátor, s podkategoriemi odpovídajícím užitému identifikačnímu řetězci (Spisová značka, Číslo jednací, Věc, Číslo stížnosti, ECLI, Sbírka zákonů, Sbírka nálezů a usnesení ÚS, Sbírka rozhodnutí NSS, Sbírka rozhodnutí a soudních stanovisek, Sbírka usnesení a nálezů ÚS ČSFR),

3. kategorií Datum rozhodnutí.

Konstituent Cíl také může obsahovat třetí atribut (Element), kterým je specifikováno přesné místo v dokumentu, na který je odkazováno. Příznaky atributu Element jsou Odstavec, který se vyskytuje v případech, kdy cílový dokument obsahuje číslování odstavců, Struktura (tu dále dělíme na kategorie Odůvodnění a Odlišné stanovisko) a Strana, v případě že odkaz mírí

\footnotetext{
22 Např́klad odkaz na rozhodnutí Německého spolkového soudu v nálezu Ústavního soudu sp. zn. Pl. ÚS 55/10 ze dne 1. 3. 2011 (80/2011 Sb., N 27/60 SbNU 279).

${ }^{23}$ Jedná se například o Soud Evropského sdružení volného obchodu, Mezinárodní trestní soud a další.
} 
na konkrétní stránku cílového dokumentu (např. v případě publikace ve sbírkách).

\subsubsection{LITERATURA ${ }^{24}$}

Druhou kategorií konstituentu CÍL je Literatura. Během anotačních cvičení a cíleného prohledávání zejména rozhodnutí Ústavního soudu jsme zjistili, že soudci příležitostně v rozhodnutích odkazují na podporu svých tezí jak k právní odborné literatuře, tak ve vzácných případech rovněž k mimoprávní i krásné literatuře nebo dokonce $\mathrm{k}$ popularizačním textům.

$\mathrm{V}$ rámci kategorie Literatura rozeznáváme čtyři nižší kategorie dělené dle druhu cílového dokumentu. První z nich je Právní odborná literatura. Soudci ve svých rozhodnutích berou na vědomí právní doktrínu a o její východiska se opírají. Argumentační síla cílového dokumentu je dána jednak přesvědčivostí nabízené argumentace a jednak, samozřejmě, věhlasností jeho autora. $^{25}$ Stojí za to uvést, že tím, že se soud rozhodne danou odbornou publikaci ocitovat, tak přímo zvyšuje její význam, a tedy i přesvědčivost, což je nutno brát jako zajímavý a důležitý projev vzájemné synergie mezi soudem a autorem odborné literatury.

Kategorie Právní literatura je za účelem bližší specifikace a usnadnění následného nakládání s výslednými daty dále dělena podle platformy publikace na kategorie Monografie (která zahrnuje rovněž kapitoly knih a celé sborníky), Komentář a Článek (publikovaný ve sborníku, odborném časopise atd.). Toto dělení jsme nakonec upřednostnili nad původně uvažovaným dělením dle věcného charakteru cílového textu na deskriptivní (de lege lata) a preskriptivní (de lege ferenda) jurisprudenci. ${ }^{26}$ Při bližší práci s touto variantou se totiž ukázalo, že nejsme schopni dostatečně jistě určit uvedený rozdíl v cílových dokumentech. $\mathrm{Z}$ toho důvodu jsme nakonec zvolili dělení dle platformy publikace. $\mathrm{V}$ omezené míře jsme však schopni určit věcný

\footnotetext{
24 Viz grafické vyjádření struktury v obr. 2.

${ }^{25}$ Viz HOECKE, Mark van. Legal Doctrine: Which Method(s) for What Kind of Discipline? In HOECKE, Mark van, ed. Methodologies of legal research: which kind of method for what kind of discipline? Oxford, Portland: Hart, 2011, s. 11-12.

${ }^{26}$ Srovnej SOBEK, Tomáš. Argumenty teorie práva. Plzeň: Vydavatelství a nakladatelství Aleš Čeněk, 2008, s. 276-277.
} 
charakter textu (normativní či deskriptivní) i skrze platformu publikace. Z toho důvodu odlišujeme komentáře od monografií. Předpokládáme, že komentáře $\mathrm{v}$ sobě obsahují převážně deskriptivní prvky, zatímco monografie v sobě budou obsahovat i prvky preskriptivní.

Druhou kategorií je Neprávní literatura, která je rovněž dále dělena dle platformy publikace na kategorie Monografie a Článek, slouží jako specifikace pro mimoprávní odborné texty. Zajímavé jsou pro nás zejména $\mathrm{z}$ hlediska přesahů práva a jiných vědních disciplín a jejich vzájemného ovlivňování. Jejich argumentační síla spočívá podobně jako $\mathrm{v}$ př́ípadě právní vědy přímo $\mathrm{v}$ přesvědčivosti prezentovaných myšlenek a jejich provedení.

Třetí kategorií je Krásná literatura. Citace krásné literatury v soudních rozhodnutích jsou netypickou figurou, která administrativně-právnímu stylu není vlastní. Svědčí tedy většinou o excesu autora, který záměrně překračuje konvenci obecně zachovávaného stylu právních textů včetně soudních rozhodnutí. Důvodů, proč tak autor činí, může být ale několik. Všechny jsou přitom z hlediska zkoumání soudních rozhodnutí relevantní a je třeba je nacházet a následně zkoumat. Citační analýza je jedinou metodou, která umožňuje literární citace zkoumat, protože je nejprve dokáže najít a následně identifikovat důvody použití a případně také smysl dané argumentace. ${ }^{27}$

Důvody použití argumentace krásnou literaturou mohou být bud’ obsahové, nebo formální. Po obsahové stránce autor pracuje s kulturním vědomostním základem, který sám sdílí s publikem a který posiluje jejich vzájemnou vazbu nebo který přibližuje argumentaci publiku díky své lepší srozumitelnosti či obecnější přístupnosti. Vždy je tu však obsahová vazba citovaného díla a řešeného prŕpadu. Taková obsahová propojenost je hodnotově zabarvená, protože vychází z hodnot sdílené kultury, vědomost-

${ }^{27}$ Srovnej HENDERSON, M. Todd. Citing fiction. The Green Bag An Entertaining Journal of Law. 2008, roč. 11, s. 171-185, GADBIN-GEORGE, Géraldine. To quote or not to quote: "Literature in law" in European court decisions and legal English teaching. ASp. la revue du GERAS. 2013, roč. 21, č. 64, s. 75-93, SMEJKALOVÁ, Terezie. Argumentace krásnou literaturou. In HAMUL'ÁK, Ondrej. Právo v umění a umění v právu: sborník odborných př́spěvků z mezinárodní konference Olomoucké debaty mladých právníků 2011. Praha: Leges, 2011. s. 23-31. 
ního základu, identity apod. Teoreticky lze tento jev vysvětlit pomocí zákonitostí právního vědomí, materiálními prameny práva, přes Gadamerovu hermeneutiku a předvědění či pomocí pojmu communion z Nové rétoriky. ${ }^{28}$ Po formální stránce může autor využívat působivost této speciální figury v podstatě jako upoutávku na argumenty, které s danou citací nemusí vůbec obsahově souviset. Sem patří např. všeobecně platné a známé citáty nebo odkazy na autority všeho druhu bez užší souvislosti. Vysvětlení tu potom nabízí především rétorika, a to jak tradiční, tak i Nová rétorika.

Zahrnutí referencí na krásnou literaturu do citační analýzy nám umožňuje stanovit, jak s tímto nástrojem posilování přesvědčivosti soudních rozhodnutí nakládají čeští soudci, zejména jak často a za jakých okolností ho používají, zda ho používají správně, či jak je navázán na jiné citace. Předchozí anotační cvičení a cílené vyhledávání prokázaly, že citace krásné literatury se objevuje zejména v rozhodnutích Ústavního soudu.

Kategorie Krásná literatura je dále dělena na kategorie Kniha a Kratší text. Tím je myšleno obecné označení pro kratší literární útvary, jako jsou např́íklad povídka a báseň.

Čtvrtou kategorií je sběrná kategorie označená jako Ostatní, která není dále členěna. Do této kategorie patří popularizační, nebo publicistické texty a hlavně tzv. šedá literatura, tedy dokumenty produkované veřejnými institucemi $v$ průběhu jejich činnosti. Jedná se zejména o různé zprávy a stanoviska komisí, výroční zprávy nebo důvodové zprávy $\mathrm{k}$ právním předpisům. Argumentační síla těchto dokumentů je dvojí. Jednak podobně jako $\mathrm{v}$ případě předchozích kategorií spočívá přímo $\mathrm{v}$ přesvědčivosti uvedených myšlenek, zároveň ale může velkou roli hrát publikační charakter dokumentu. To je př́pad šedé literatury, kdy například pro určité druhy výkladu právních předpisů jsou zásadní důvodové zprávy. ${ }^{29}$

Konstituent Cíl kategorie Literatura je dále přesně identifikován za pomoci kategorie Název, která jednoznačně identifikuje cílový dokument za pomoci př́iznaků Autor (jméno autora) a Titul (samotný název díla). Ve

\footnotetext{
${ }^{28}$ Viz PERELMAN, Chaïm a Lucie OLBRECHTS-TYTECA. The new rhetoric: a treatise on argumentation. Notre Dame: University of Notre Dame Press, 2008, 566 s.

${ }^{29}$ KNAPP, Viktor. Teorie práva. Praha: C.H. Beck, 1999, s. 170-173.
} 
specifickém případě šedé literatury je jako autor označen název instituce (nebo orgánu), která dokument vydala. Konkrétní místo v cílovém dokumentu je jednoznačně identifikováno za pomoci kategorie Element, která obsahuje příznaky Kapitola a Strana. Díky zaznačení těchto kategorií je možné snadno a jednoznačně určit konkrétní místo, ze kterého pochází myšlenky, kterými soud podkládá svoji argumentaci.

\section{ARGUMENT ${ }^{30}$}

Reference složená pouze ze dvou konstituentů (ZDROJ a CÍL) je informačně velmi chudá a neumožňuje nám zohlednit multidimenzionální povahu každého citovaného zdroje. $\mathrm{Z}$ toho důvodu jsme zavedli třetí konstituent, ARGUMENT. Je jím myšleno abstraktní zobecnění toho, co chce soudce danou referencí sdělit, tedy proč danou referenci uvádí. ${ }^{31}$

Konstituent ARGUMENT dělíme dále dle typu reference na kategorie Citace, Parafráze, Tvrzení a zbytkovou kategorii Ostatní. Tímto dělením je vyjádřen způsob, jakým v textu rozhodnutí soud na argument v cílovém dokumentu odkazuje. Při provádění citační analýzy je toto dělení zajímavé proto, že vypovídá o způsobu citační praxe soudu (a podpůrných argumentů), případně kolik práce si s odkazováním soudce dal.

Jako citace je reference vyhodnocena, když je ve zdrojovém rozhodnutí ARGUMENT formulován jako přímá citace jiného dokumentu, nejčastěji je tedy ohraničen uvozovkami nebo řezem písma kurzíva.

O parafrázi hovoříme tehdy, když nedoslovně přebírá myšlenky z cílového dokumentu. Může jít o část cílového dokumentu, případně o shrnutí dokumentu jako celku, kdy v jednom odstavci rozhodnutí soud stručně shrne a představí meritum cílového dokumentu.

\footnotetext{
30 Viz grafické vyjádření struktury v obr. 3.

31 Může tak jít například o výklad pojmu „rovnost“, jako je to v případě nálezu Ústavního soudu sp. zn. Pl. ÚS 33/96 (185/1997 Sb., N 67/8 SbNU 163) v referencích na nálezy Ústavního soudu sp. zn. Pl. ÚS 22/92, Pl. ÚS 36/93 (132/1994 Sb., N 24/1 SbNU 175), Pl. ÚS 16/93 (131/1994 Sb., N 25/1 SbNU 189), Pl. ÚS 5/95 (6/1996 Sb., N 74/4 SbNU 205) a Pl. ÚS 9/95 (107/1996 Sb., N 16/5 SbNU 107), nebo o zdůraznění důležitosti hodnoty práva na dobré jméno a ochranu osobnosti jako je to v případě nálezu Ústavního soudu sp. zn. I. ÚS 453/03 (N 209/39 SbNU 215), ve které je reference na krásnou literaturu - Knihu př́isloví, kap. XXII v.1, Kaz. 7.1.
} 
Jako kategorií Tvrzení identifikujeme soudem vyjádřený názor, který je opřen o cílový dokument nebo dokumenty. Často se jedná o reference, které odkazují na více dokumentů. Rozdíl mezi parafrází a tvrzením spočívá $\mathrm{v}$ tom, že zatímco u parafráze zdroj odkazuje na konkrétní místo $\mathrm{v}$ cílovém dokumentu a vlastními slovy shrnuje jeho obsah (případně obecněji shrnuje obsah celého dokumentu), $\mathrm{v}$ př́ípadě tvrzení je odkázáno na cílový dokument jako celek, ale není již podrobněji uveden jeho obsah.

\section{POLARITA ${ }^{32}$}

Ze tří konstituentů (ZDROJ, CÍL a ARGUMENT) lze získat informaci o tom, ze kterého dokumentu odkazuje na který, a co je podstatou jejího sdělení. Ty však nevypovídají nic o tom, jak se k uvedenému argumentu daný soud staví. Na základě zahraniční zkušenosti, zejména se systémy common law, jsme se rozhodli zavést čtvrtý konstituent, kterým je POLARITA. Tato vlastnost reference říká, jak se daný soud $\mathrm{k}$ cíli a argumentu staví, zda s ním souhlasí, nebo zda se proti němu vymezuje. $\mathrm{V}$ metodologii rozlišujeme polaritu pozitivní, neutrální a negativní. Obecně je možné uvést, že soudy necitují judikaturu, se kterou by, byt implicitně nesouhlasily. Zároveň ale máme za to, že takto nízko nastavená úroveň vyjádření souhlasu s rozhodnutím by způsobila, že by převážné množství referencí bylo pozitivních, což by snižovalo popisnou hodnotu tohoto konstituentu. Pozitivní či negativní postoj soudu k cíli proto musí být vyjádřen explicitně. Neutrální polarita tak pro nás představuje jakousi zbytkovou kategorii, do které bude spadat většina referencí, ke kterým soud implicitně zaujímá pozitivní postoj.

Na základě zkušenosti $\mathrm{z}$ výše uvedených anotačních cvičení jsme však objevili zásadní rozdíl oproti zahraniční praxi. Polarita referencí je v české rozhodovací praxi totiž převážně neutrální (neobsahuje tedy explicitní určení toho, jestli soud s rozhodnutím souhlasí či naopak nesouhlasí).

Konstituent POLARITA zahrnuje dvě kategorie: Hodnotu a Koeficient. Kategorie Hodnota je dále dělena na kategorie Pozitivní, Negativní a Neutrální. Pomocí těch je reference hodnotově specifikována dle toho, $\mathrm{v}$ jakém kontextu ji soud užil, tedy jestli soud argumentaci, na kterou odkazuje,

32 Viz grafické vyjádření struktury v obr. 4. 
hodnotí pozitivně, negativně, nebo neutrálně. Hodnocení, do které kategorie Hodnoty bude reference zařazena, je nutné odvodit z celého kontextu, ve kterém se reference vyskytuje. Pokud není možné jednoznačně říct, že výrok je hodnocen kladně, nebo záporně, je zařazen do kategorie neutrální. Předchozí zkušenosti ukázaly, že naprostá většina referencí bude zařazena právě do této neutrální kategorie.

Druhou kategorií je pak Koeficient, který určuje, do jaké hloubky se soud citovaným rozhodnutím zaobíral - rozlišujeme mezi prostým citováním a hlubší diskuzí. Máme za to, že u citovaného zdroje, který je diskutován, nese vyjádření citujícího soudu větší váhu, než prostá citace rozhodnutí na podporu či vyvrácení názoru. ${ }^{33}$ Hodnota Koeficientu tak funguje jako modifikátor kategorie Hodnota.

\section{ZÁVĚR: VÝZVY}

V tomto textu jsme představili definované kategorie pro manuální a posléze automatickou anotaci citací. Kategorie a jejich struktura jsou výsledkem širšího konsenzu týmu tak, aby nám umožnily postihnout multidimenzionální charakter citací. Nad rámec běžně užívaných konstituentů ZDROJ a CÍL, které umožňují sledovat citace konkrétních dokumentů jinými, jsme na základě zahraničních zkušeností zařadili i konstituenty ARGUMENT a POLARITA. Ty, jak vě̌íme, umožní zvýšit užitečnost citační analýzy. Vzhledem $\mathrm{k}$ chybějícímu citačnímu standardu jsou shora uvedené konstituenty strukturovány tak, abychom mohli zohlednit, jakým způsobem jsou v textu vyjádřeny. Věříme, že manuálně anotovaný zlatý standard, který zohlední tuto vnitřní strukturu, nám umožní dosáhnout lepších výsledků automatické anotace.

Předkládaný text a z něj vycházející anotační manuál mají zcela zásadní nevýhodu - vyžadují netriviální množství práce $\mathrm{k}$ tomu, aby mohly být aplikovány pro anotace. $\mathrm{V}$ rámci manuálních anotací je totiž nutné vyškolit dostatečné množství anotátorů, aby byla sbíraná data přiměřeně konzistent-

\footnotetext{
33 Srov. LIU, John S., Hsiao-Hui CHEN, Mei Hsiu-Ching HO a Yu-Chen LI. Citations with different levels of relevancy: Tracing the main paths of legal opinions. Journal of the Association for Information Science and Technology, 2014, roč. 65, č. 12, s. 2479-2488.
} 
ní. Čím více je jednotlivých kategorií a čím komplikovanější je jejich vnitřní třídění, tím složitějši je vyškolit anotátory pro jejich využití. V závislosti na anotačním rozhraní použitém pro samotný sběr dat tak bude nutné postupným zkoušením předložené anotační schéma (můžeme jej nazvat idealizovaným) postupně zjednodušovat. Zjednodušená verze by měla být kompromisem mezi náročností manuálních anotací (prostř̌edky vynaložené na školení $\mathrm{v}$ kombinaci s prostředky vynaloženými na anotaci dokumentu - např. $v$ případě použití složitějšího schématu bude nutné věnovat anotacím více času) a vynaloženými časovými i finančními prostředky. Experimenty, které by měly vést ke zjednodušení a $k$ dosažení praktické použitelnosti předloženého idealizovaného schématu tak probíhají v současné době.

\section{BIBLIOGRAFIE}

[1] BAŇOUCH, Hynek a Zdeněk KÜHN. O publikaci a citaci judikatury aneb proč je někdy judikatura jako císařovy nové šaty. Právní rozhledy, 2005, roč. 13, č. 13, s. 484-495. ISSN 12106410 .

[2] BOBEK, Michal, Zdeněk KÜHN a kol. Judikatura a právní argumentace. 2. Vydání. Praha: Auditorium, 2013, 496 s. ISBN 978-80-87284-35.

[3] CROSS, Frank. Determinants of Citations to Supreme Court Opinions (And the Remarkable Influence of Justice Scalia). Supreme Court Economic Review, 2010, roč. 18, č. 1, s. 177-202. ISSN 0736-9921.

[4] DERLÉN, Mattias a Johan LINDHOLM. Goodbye van Gend en Loos, Hello Bosman? Using Network Analysis to Measure the Importance of Individual CJEU Judgments. European Law Journal, 2014, roč. 20, č. 5, s. 667-687. ISSN 1468-0386.

[5] FOWLER, James H. et al. Network Analysis and the Law: Measuring the Legal Importance of Precedents at the U.S. Supreme Court. Political Analysis, 2007, roč. 15, č. 3, s. 324-346. ISSN 1047-1987.

[6] FOWLER, James H. a Sangick JEON. The Authority of Supreme Court Precedent. Social Networks, 2008, roč. 30, č. 1, s. 16-30. ISSN 0378-8733.

[7] GADBIN-GEORGE, Géraldine. To quote or not to quote: "Literature in law" in European court decisions and legal English teaching. ASp. la revue du GERAS. 2013, roč. 21, č. 64, s. 7593. ISSN 2108-6354.

[8] GARFIELD, Eugene. Citation Indexes for Science. Science, 1955, roč. 122, č. 3159, s. 108111. ISSN 0036-8075. 
[9] GEIST, Anton. Using Citation Analysis Techniques for Computer-Assisted Legal Research in Continental Jurisdictions. Kvalifikační práce (University of Edinburgh, LLM) [online]. 2009, 103 s. [vid. 31. května 2017]. Dostupné z: https://www.era.lib.ed.ac.uk/bitstream/ handle/1842/3511/GeistLLM2009.pdf?sequence $=2$.

[10] GEIST, Anton. The Open Revolution: Using Citation Analysis to Improve Legal Text Retrieval. European Journal of Legal Studies, 2010, roč. 2, č. 3. ISSN 1973-2937.

[11] HAMANN, Hanjo. Die Fußnote, das unbekannte Wesen. Potential und Grenzen juristischer Zitationsanalyse. Rechtswissenschaft. Zeitschrift für rechtswissenschaftliche Forschung, 2014, roč. 5, č. 4, s. 501-534. ISSN 1868-8098.

[12] HARAŠTA, Jakub. K významu citační analýzy při aplikaci práva. Správní právo, 2017, roč. 50, č. 3, s. 154-162. ISSN 0139-6005.

[13] HARAŠTA, Jakub. Nejednoznačnost odkazů k soudním rozhodnutím a možnost řešení. Revue pro právo a technologie, 2015, roč. 6, č. 11, s. 15-28. ISSN 1805-2797.

[14] HENDERSON, M. Todd. Citing fiction. The Green Bag An Entertaining Journal of Law. 2008, roč. 11, s. 171-185. ISSN 1095-5216.

[15] HOECKE, Mark van. Legal Doctrine: Which Method(s) for What Kind of Discipline? In: HOECKE, Mark van, ed. Methodologies of legal research: which kind of method for what kind of discipline? Oxford, Portland: Hart, 2011, s. 294. ISBN 978-1-849-46499-4.

[16] KNAPP, Viktor. Teorie práva. Praha: C.H. Beck, 1999, 264 s. ISBN 80-7179-028-1.

[17] LANDES, William a Richard A. POSNER. Legal Precedent: A Theoretical and Empirical Analysis. The Journal of Law \& Economics, 1976, roč. 19, č. 2, s. 249-307. ISSN 0022-2186.

[18] LIEBLER, Raizel a June LIEBERT. Something Rotten in the State of Legal Citation: The Life Span of a United States Supreme Court Citation Containing an Internet Link (1996-2010). Yale Journal of Law \& Technology, 2013, roč. 15, č. 2, s. 273-311.

[19] LIU, John S., Hsiao-Hui CHEN, Mei Hsiu-Ching HO a Yu-Chen LI. Citations with different levels of relevancy: Tracing the main paths of legal opinions. Journal of the Association for Information Science and Technology, 2014, roč. 65, č. 12, s. 2479-2488. ISSN 2330-1643.

[20] LUPU, Yoanatan a Erik VOETEN. Precedent in International Courts: A Network Analysis of Case Citations by the European Court of Human Rights. British Journal of Political Sciences, 2012, roč. 42, č. 2, s. 413-439. ISSN 0007-1234.

[21] MACCORMICK, Neil a Robert S. SUMMERS. Interpreting precedents: a comparative study. Aldershot: Ashgate, 1997, 585 s. ISBN 978-1-138-27024-4.

[22] MYŠKA, Matěj, Jakub HARAŠTA, Pavel LOUTOCKÝ a Jakub MÍŠEK. Možnosti citační analýzy v České republice. Revue pro právo a technologie, Masarykova univerzita, 2016, roč. 7, č. 13, s. 147-189. ISSN 1804-5383.

[23] NEALE, Thom. Citation Analysis of Canadian Case Law. Journal of Open Access to Law, 2013, roč. 1, č. 1, s. 1-60. ISSN 2372-7152. 
[24] PANAGIS, Yannis a Urška Šadl. Making EU (case)law: Evidence from a paragraph-toparagraph network on the cases concerning the citizenship of the European Union. In Proceedings of the 15th International Conference on Artificial Intelligence and Law (ICAIL 2015), Law and Big Data Workshop. San Diego, 2015, s. 1-8.

[25] PANAGIS, Ioannis a Urška ŠADL. The force of EU case law: An empirical study of precedential constraint. In Legal Knowledge and Information Systems - JURIX 2015: 28th Annual Conference. Amsterdam: IOS Press BV, 2015, s. 71-80. ISBN 978-1-61499-608-8.

[26] PERELMAN, Chaïm a Lucie OLBRECHTS-TYTECA. The new rhetoric: a treatise on argumentation. Notre Dame: University of Notre Dame Press, 2008, 566 s. ISBN 978-0-268-004460 .

[27] POSNER, Richard A. An Economic Analysis of the Use of Citations in the Law. American Law and Economics Review, 2000, roč. 2, č. 2, s. 381-406. ISSN 1465-7260.

[28] PRICE, Derek J. de Solla. Network of Scientific Papers. Science, 1965, roč. 149, č. 3683, s. 510-515. ISSN 0036-8075.

[29] SASALA, Kathleen M. Shepardizing and Keyciting online [online]. March 25, 2011 [vid. 31. května 2017]. Dostupné z: http://www.clelaw.lib.oh.us/public/misc/Shepardizing\%20and \%20KeyCiting.html.

[30] SHULAYEVA, Olga, Advaith SIDDHARTHAN a Adam WYNER. Recognizing Cited Facts and Principles in Legal Judgements. Artificial Intelligence and Law, 2017, roč. 25, č. 1, s. 107126. ISSN 1572-8382.

[31] SMEJKALOVÁ, Terezie. Argumentace krásnou literaturou. In HAMULÁK, Ondrej. Právo $v$ uměni a umění v právu: sborník odborných př́spěvků z mezinárodní konference Olomoucké debaty mladých právníků 2011. Praha: Leges, 2011. s. 23-31. ISBN 978-80-87576-14-4.

[32] SOBEK, Tomáš. Argumenty teorie práva. Plzeň: Vydavatelství a nakladatelství Aleš Čeněk, 2008, 330 s. Ediční řada Ústavu státu a práva AVČR. ISBN 978-80-904024-5-4.

[33] WINKELS, Radboud, Jelle de RUYTER a Henryk KROESE. Determining the Authority of Dutch Case Law. In ATKINSON, Katie (ed.). Legal Knowledge and Information Systems JURIX 2011: The Twenty-Fourth Annual Conference. Amsterdam: IOS Press BV, 2011, s. 103-112. ISBN 978-1-607-50980-6

[34] WINKELS, Radboud a Jelle de RUYTER. Survival of the Fittest: Network Analysis of Dutch Supreme Court Cases. In PALMIRANI, Monika, Ugo PAGALlO, Pompeu CASANOVAS a Giovanni SARTOR (eds.). AI Approaches to the Complexity of Legal Systems - Models and Ethical Challenges for Legal Systems, Legal Language and Legal Ontologies, Argumentation and Software Agents, Berlin: Springer, 2012, s. 106-115. ISBN 978-3-642-35730-5.

Toto dílo lze užít v souladu s licenčními podmínkami Creative Commons BY-SA 4.0 International (http://creativecommons.org/licenses/by-sa/4.0/legalcode). 
